\title{
Распределение фитолитов по почвенному профилю заболоченного луга (Северная Кулунда)
}

\section{Phytoliths distribution by swampy meadow soil profile (North Kulunda)}

\author{
Парадосский В. Л. \\ Paradossky V. L. \\ Алтайский государственный университет, г. Барнаул, Россия.E-mail: paradossky@mail.ru \\ Altai State University, Barnaul, Russia
}

Peфepam. В статье представлены результаты анализа фитолитного профиля заболоченного луга на территории севера Кулундинской степи. Получены данные об изменении состава фитоценоза на локальном участке. В настоящее время в видовом составе преобладают Saussurea amara L. D. C. и Scolochloa festucacea (Willd.) Link. Ha ocнове распределения фитолитов по почвенному профилю сделано заключение о наличии тростникового болота на этой территории около 4000 лет назад.

Ключевые слова. Заболоченный луг, север Кулундинской степи, фитолиты, Saussurea amara, Scolochloa festucacea.

Summary. The article presents the results of the analysis of the phytolithic profile of a marshy meadow in the north of the Kulunda steppe. The data on the changing of phytocenosis structure in the local area were obtained. At the present time Saussurea amara L. D. C. and Scolochloa festucacea (Willd.) Link. dominate in species composition. Based on the distribution of phytoliths over the soil profile, it was concluded that there was a reed swamp in this area about 4,000 years ago.

Key words. Marshy meadow, north of the Kulunda steppe, Saussurea amara, Scolochloa festucacea, phytolites.

\section{Введение}

Фитолиты - это микроскопические частицы кремневой природы, оригинальной формы, формирующиеся в растениях и позволяющие идентифицировать его спустя длительное время. Отличия форм фитолитов и их размеров у некоторых растений могут использоваться при реконструкции естественной и культурной растительности методом фитолитного анализа (Силантьева и др., 2014).

Фитолитный анализ позволяет получать важные данные по локальной растительности степных и лесостепных территорий. По данным исследований фитолитных спектров растительных сообществ в энеолите растительность Северной Кулунды характеризовалась значительным участием хвойных лесов и луговых растительных сообществ по сравнению с настоящим временем. Изменения растительности локальных территорий Северной Кулунды во второй половине голоцена проходили в три этапа: 1) уменьшение площадей лесов, смена их степными растительными сообществами, остепнение луговых и лугово-степных фитоценозов во время существования энеолитических поселений; 2) восстановление луговых растительных сообществ после снижения антропогенной нагрузки; 3) остепнение растительного покрова в современный период антропогеогенеза (Соломонова и др., 2015).

\section{Объект исследования}

Соссюрейно-тростянковый заболоченный луг находится вблизи археологического объекта Новоильинка-VI, 3 км восточнее с. Новоильинка (Хабарский район). Общее проективное покрытие 100 \%. Доминируют: Saussurea amara L. D.C. и Scolochloa festucacea (Willd.) Link. В травостое обилие гигрофитов: Alopecurus arundinaceus Poir., Bolboschoenus planiculmis (F. Schmidt) T.V. Egorova, Phragmites australis (Cav.) Trin. ex Steud. Среди злаков также встречается Agrostis gigantea Roth . Обильна доля раз- 
Фитолитный профиль соссюрейно-тростянкового заболоченного луга

\begin{tabular}{|c|c|c|c|c|c|c|c|c|c|c|}
\hline \multirow[t]{3}{*}{ Морфотипы } & \multicolumn{10}{|c|}{ Глубина почвенного профиля } \\
\hline & $0-5$ & $5-10$ & $10-15$ & $15-20$ & $20-25$ & $25-30$ & $30-35$ & $35-40$ & $49-45$ & $45-50$ \\
\hline & \multicolumn{10}{|c|}{ Количество фитолитов, \% } \\
\hline Пузыревидные частицы & 4,8 & 6,7 & 10,4 & 15,1 & 20,5 & 27,6 & 38,7 & 34,0 & 46,0 & 44,9 \\
\hline Волнистые пластинки & 1,3 & & & & 0,5 & & & & & \\
\hline $\begin{array}{l}\text { Полилопастные тра- } \\
\text { пециевидные частицы }\end{array}$ & 2,6 & & & & 0,3 & 0,6 & 0,3 & & & \\
\hline $\begin{array}{l}\text { Настоящие двулопаст- } \\
\text { ные частицы }\end{array}$ & & 0,7 & & & & & & & & \\
\hline $\begin{array}{l}\text { Двулопастные частицы } \\
\text { Stipa-типа }\end{array}$ & 0,3 & & & & & & & & & \\
\hline $\begin{array}{l}\text { Трапециевидный } \\
\text { рондель }\end{array}$ & 13,5 & 9,4 & 6,6 & 3,8 & 8,6 & 1,6 & 1,2 & 0,9 & & \\
\hline Конический рондель & 6,4 & 5,7 & 4,8 & 6,3 & 5,4 & 2,9 & 1,5 & & & \\
\hline Килиевидный рондель & 1,6 & 2,7 & 2,6 & 0,9 & 0,8 & 0,3 & 0,3 & & & \\
\hline Седловидный рондель & 1,9 & 3,3 & 4,4 & 3,5 & 1,9 & 1,0 & & & 0,6 & \\
\hline $\begin{array}{l}\text { Воронковидные кониче- } \\
\text { ские частицы }\end{array}$ & 0,3 & 1,0 & 0,3 & 1,6 & 0,3 & 0,3 & & & 1,0 & \\
\hline $\begin{array}{l}\text { Блочные структуры с } \\
\text { порами }\end{array}$ & 1,3 & 1,0 & 0,6 & 1,3 & 2,7 & 4,2 & 3,6 & 1,9 & 1,3 & 0,7 \\
\hline $\begin{array}{l}\text { Блочные структуры без } \\
\text { пор }\end{array}$ & 0,6 & 2,3 & 2,5 & 3,1 & 3,2 & 1,0 & & 1,0 & 0,3 & 1,8 \\
\hline $\begin{array}{l}\text { Трахеиды хвойных с } \\
\text { порами }\end{array}$ & & & 0,6 & 0,6 & 1,3 & 2,6 & 1,2 & 0,6 & 0,6 & \\
\hline $\begin{array}{l}\text { Ланцетные частицы с } \\
\text { массивным основанием }\end{array}$ & 10,3 & 6,7 & 11,0 & 11,9 & 8,9 & 9,7 & 3,3 & 3,2 & 3,2 & 1,5 \\
\hline $\begin{array}{l}\text { Ланцетные клетки с } \\
\text { удлинённым шипом }\end{array}$ & 2,6 & 2,3 & 4,1 & & 3,8 & 0,3 & 2,1 & 0,3 & 1,0 & 1,8 \\
\hline $\begin{array}{l}\text { Ланцетные клетки } \\
\text { треугольной формы }\end{array}$ & & & & & & & 1,2 & 1,6 & 6,7 & 4,4 \\
\hline $\begin{array}{l}\text { Длинные округлые } \\
\text { частицы }\end{array}$ & 17,0 & 17,0 & 11,4 & 10,1 & 11,3 & 14,9 & 9,8 & 16,2 & 16,5 & 6,6 \\
\hline $\begin{array}{l}\text { Длинные ребристые } \\
\text { частицы }\end{array}$ & 2,9 & 3,3 & 0,9 & 2,2 & 2,7 & 1,9 & 4,2 & 3,8 & 0,3 & 0,7 \\
\hline $\begin{array}{l}\text { Длинные перфориро- } \\
\text { ванные частицы }\end{array}$ & 0,3 & 0,3 & 1,6 & 5,0 & 4,6 & 8,1 & 10,7 & 5,1 & 7,3 & 9,2 \\
\hline $\begin{array}{l}\text { Длинные мелкозубча- } \\
\text { тые частицы }\end{array}$ & 1,3 & & 2,2 & 3,1 & 1,3 & 1,9 & 1,2 & 1,0 & 1,0 & 1,8 \\
\hline $\begin{array}{l}\text { Длинные волнистые } \\
\text { частицы }\end{array}$ & 4,8 & 1,3 & 3,2 & 3,1 & 5,9 & 6,2 & & 0,3 & & \\
\hline $\begin{array}{l}\text { Длинные трёхгранные } \\
\text { частицы }\end{array}$ & & & & & & & 0,6 & 1,3 & 0,6 & \\
\hline $\begin{array}{l}\text { Пластинки прямоуголь- } \\
\text { ной формы }\end{array}$ & 8,3 & 12,3 & 9,1 & 7,5 & 1,6 & 6,5 & 6,3 & 12,7 & 7,0 & 14,0 \\
\hline $\begin{array}{l}\text { Пластинки неправиль- } \\
\text { ной формы }\end{array}$ & 3,2 & 6,7 & 6,3 & 2,8 & 2,7 & 3,9 & 8,3 & 6,3 & 3,2 & 7,0 \\
\hline $\begin{array}{l}\text { Пластинки округлой } \\
\text { формы }\end{array}$ & 1,0 & & & & 1,1 & 0,6 & 3,0 & 4,1 & 1,3 & 1,1 \\
\hline $\begin{array}{l}\text { Прочие формы } \\
\text { фитолитов }\end{array}$ & 13,7 & 17,3 & 17,4 & 17,9 & 10,4 & 3,5 & 2,7 & 5,7 & 2,1 & 4,5 \\
\hline
\end{tabular}


нотравья: Inula britannica L., Lactuca tatarica (L.) C.A. May., Lycopus exaltatus L., Stachys palustris L., Plantago cornuti Gouan, Potentilla anserine L. Пробы почвы были отобраны колонкой через каждые 5 см. Почвы на участке торфяно-болотные, глубина торфа до 50 см от поверхности. С глубины 42-52 см были отобраны пробы для радиоуглеродного датирование. Была получена дата $4210 \pm 130$ л.н. (Гольева, Кирюшин, 2015).

\section{Материалы и методы}

Изучение фитолитов производилось под микроскопом Olympus BX-51 с помощью цифровой камеры Olympus XC-50 и программного обеспечения cellSens Standard под увеличением объектива х20. Подсчет производился до 300 экземпляров с одной пробы.

Для классификации фитолитов по формам были использованы: Международный код номенклатуры фитолитов (Madella et al., 2005), рекомендации М. С. Блинникова к русификации названий морфотипов фитолитов (Блинников, 2018). Морфотипы фитолитов были определены на основе иллюстративного материала по территории Северного Алтая (Solomonova et al., 2019). Для интерпретации результатов были использованы классификация фитолитных спектров фитоценозов А. А. Гольевой (Гольева, $2001)$ и исследования фитолитов растений и фитолитных спектров Северной Кулунды (Лада, Гаврилов, 2016; Соломонова и др., 2015; Сперанская и др., 2016; Solomonova et al., 2018a).

\section{Результаты и обсуждения}

Фитолитный профиль сформирован до глубины 50 см и приурочен к слою торфа. Глубже, в отложениях озерной сапропели, фитолиты единичны или отсутствуют. При анализе данных были выявлены различия по ряду специфических морфотипов на разной глубине профиля (табл. 1). Количество пузыревидных частиц увеличивается с глубиной профиля и доминирует, начиная с 25 см. Этот морфотип формируется у некоторых гигрофильных злаков, на территории умеренных широт, обильно отмечен у Phragmites (Гольева, 2001).В существующем на настоящий момент времени растительном сообществе присутствует Phragmites australis в небольшом числе. Распределение его морфотипов в профиле указывает на то, что ранее вид доминировал на этом участке. Количество ронделей уменьшается с глубиной профиля. Это связано с тем, что подобные морфотипы формируются преимущественно у ксерофитов и мезофитов (Сперанская и др. 2018). В верхних слоях профиля содержится большое число ланцетных частиц. Это соответствует составу современного растительного сообщества. Фитолиты в форме ланцетных частиц формируются в значительном числе у мезофильных злаков, осок и некоторых других представителей однодольных (Сперанская и др., 2018, Solomonova et al., 2018b). Доля ланцетных частиц снижается с глубиной профиля. Для объяснения этого явления данных недостаточно. В распределении длинных частиц по профилю не наблюдается значительных изменений с глубиной.

\section{Заключение}

Полученные данные по фитолитному профилю почвы заболоченного луга на территории Северной Кулунды свидетельствуют о смене растительности на исследуемом участке во второй половине голоцена. При зарастании озера около 4000 лет назад изначально на участке было тростниковое болото (Phragmites australis). Эти результаты согласуются с данными о микробиоморфном составе этого почвенного профиля (Парадосский, 2018) и сведениями о функционировании территории во второй половине голоцена и её гидрологическим режимом (Гольева, Кирюшин, 2015).

\section{ЛИТЕРАТУРА}

Блинников М. С. К вопросу о стандартизации русских названий морфотипов фитолитов злаков средних широт Северного полушария // Проблемы ботаники Южной Сибири и Монголии: XVII Международная науч.-практич. конф. - Барнаул, 2018. - С. 277-280.

Гольева $\boldsymbol{A}$. $\boldsymbol{A}$. Фитолиты и их информационная роль в изучении природных и археологических объектов. - Москва - Сыктывкар: Элиста, Полтекс, 2001. - 140 с.

Гольева А. А., Кирюшин К. Ю. Характеристика ландшафтов периода функционирования поселения Новоильинка-VI по данным естественных наук // Археология Западной Сибири и Алтая: опыт междисциплинарных 
исследований: сборник статей, посвященный 70-летию профессора Ю. Ф. Кирюшина / под ред. А. А. Тишкина. Барнаул: Изд-во АлтГУ, 2015. - С. 110-115.

Лада Н. Ю., Гаврилов Д. А. Анализ фитолитного состава основных растений степных экосистем Западной Сибири // Вестник Томского государственного университета. Биология, 2016. - № 2 (34). - С. 53-68. Парадосский $\boldsymbol{B}$. Л. Микробиоморфный комплекс заболоченного луга Северной Кулунды// Перспективы развития и проблемы современной ботаники: сб. науч. ст. по материалам IV (VI) Всероссийской молодежной конференции с участием иностранных ученых (г. Новосибирск, 8-12 мая 2018 г.) / Отв. ред. А. П. Беланова. - Новосибирск: Изд-во «Академиздат», 2018. - С. 168-171.

Силантьева М. М., Сперанская Н. Ю., Соломонова М. Ю. Реконструкция эволюции растительного покрова степного фитоценоза Кулунды // Вестник алтайской науки, 2014. - № 1. - С. 198-203.

Силантьева М. М., Сперанская Н. Ю., Гальцова Т. В. Разнообразие фитолитов видов р. Setaria на юге Западной Сибири // Известия АлтГУ, 2013. - № 3-2 (79). - С. 99-102.

Соломонова М. Ю., Сперанская Н. Ю., Силантьева М. М., Митус А. Ю. Встречаемость фитолитов в форме трапециевидных коротких частиц у злаков различных эколого-ценотических групп юга Западной Сибири // Проблемы ботаники Южной Сибири и Монголии, 2015. - № 14. - С. 295-300.

Сперанская Н. Ю., Соломонова М. Ю., Гейнрих Ю. В. Диагностические формы фитолитов луговых и степных фитоценозов Алтайского края // Динамика окружающей среды и глобальные изменения климата. 2016. - Т. 7. № 1 (13). - C. 148-154.

Сперанская Н. Ю., Соломонова М. Ю., Силантьева М. М., Гейнрих Ю. В., Блинников М. С. Фитолиты злаков Северного Алтая //UkrainianJournalofEcology, 2018. - №8(1) - С. 762-771.

Madella M., Alexandre A., Ball T. Internetional Code for Phytolith Nomenclature 1.0 // Annals of Botany, 2005. Vol. 96. - P. 253-260.

Solomonova M. Y., Blinnikov M. S., Silantieva M. M., Speranskaya N. Y. Influence of Moisture and Temperature Regimes on the Phytolith Assemblage Composition of Mountain Ecosystems of the Mid Latitudes: A Case Study From the Altay Mountains // Frontiers in Ecology and Evolution. DOI:10.3389/fevo.2019.00002

Solomonova M. Yu, Silanteva M. M. Speranskaya N. Yu. Eco- cenotic characteristics of phytoliths spectra for steppe phytocenosises soils and phytoliths composition grasses of the North and South Kulunda // IOP Conf. Ser.: Earth Environ., 2018a. DOI: 10.1088/1755-1315/201/1/012024

Solomonova M. Y. , Speranskaya N. Y., Blinnikov M. S., Kharitonova E. Y., Pechatnova Y. V., Silantieva M. M. Cyperaceae Juss. and Juncaceae A. Rich ex Kunt. phytoliths of Western Siberia // Ukrainian Journal of Ecology 2018b. - №8(4). - C. 332-334. 